\title{
Concentration of IgG antibodies against food allergens in patients with irritable bowel syndrome and healthy individuals
}

\author{
Stężenie IgG przeciwko alergenom pokarmowym u pacjentów z zespołem jelita \\ nadwrażliwego i osób zdrowych
}

\author{
Iwona Traczyk ${ }^{1}$, Mirosław Jarosz ${ }^{1}$, Ryszard Tomasiuk², Wioleta Respondek ${ }^{1}$ \\ 1Department of Dietetics and Nutrition in Hospitals with Clinic of Metabolic Diseases and Gastroenterology, National Food \\ and Nutrition Institute, Warsaw, Poland \\ 2Biochemistry Department, Mazovian Regional Hospital, Warsaw, Poland
}

Przegląd Gastroenterologiczny 2011; 6 (6): 382-387

DOI: $10.5114 / p g .2011 .25994$

Key words: IgG antibodies, irritable bowel syndrome.

Słowa kluczowe: przeciwciała IgG, zespół jelita nadwrażliwego.

Address for correspondence: Iwona Traczyk PhD, National Food and Nutrition Institute, 61/63 Powsinska, 02-903 Warsaw, Poland, phone: +48 2255096 77, fax: +48 2284211 03, e-mail: itraczyk@izz.waw.pl

\begin{abstract}
Introduction: In recent years the hypothesis that irritable bowel syndrome (IBS) symptoms result from allergies or food intolerance which have not been identified has been gaining more and more supporters. Attempts are being made to find a connection between the symptoms identified in patients with IBS and food allergy, particularly IgG-dependent. The results obtained do not give a definite answer.

Aim: Evaluation the usefulness of tests for immunoglobulin G (IgG) in patients with IBS against food allergens and the possible use of the obtained results for the introduction of an elimination diet.

Material and methods: The study included 100 patients with IBS treated at the Gastrological Clinic of Brodnowski Regional Hospital in Warsaw. The control group consisted of 50 healthy individuals. IgG antibodies in the serum were tested against eight mixes of food allergens The concentration of antibodies was examined by an enzyme immunoassay test. Calculations were performed in Stata v.10.

Results: Positive tests denoting the concentrations were found in more than $90 \%$ of patients with IBS. For the three tested mixtures of allergens, all the results were positive, and the remaining positive IgG titre occurred in at least $95 \%$ of the patients. In the control group results were similar. Conclusions:

1. Determination of IgG is not applicable to the diagnosis of food allergies and dietary modification in patients with IBS.
\end{abstract}

\section{Streszczenie}

Wstęp: W ostatnich latach coraz więcej zwolenników zyskuje hipoteza, że objawy zespołu jelita nadwrażliwego (ZJN) wynikają z alergii lub nietolerancji pokarmowej, które nie zostały rozpoznane. Podejmowane są próby znalezienia związku pomiędzy dolegliwościami stwierdzanymi u pacjentów z rozpoznanym ZJN a alergią pokarmową, szczególnie IgG-zależną. Uzyskiwane wyniki nie dają jednoznacznej odpowiedzi.

Cel: Ocena przydatności wykonywania badań w kierunku immunoglobulin klasy G (IgG) przeciwko alergenom pokarmowym u pacjentów z ZJN i możliwości wykorzystania uzyskanych wyników do wprowadzenia diety eliminacyjnej.

Materiał i metody: Badania przeprowadzono w grupie 100 pacjentów z ZJN leczonych w Poradni Gastrologicznej Wojewódzkiego Szpitala Bródnowskiego w Warszawie. Grupę kontrolną stanowiło 50 zdrowych osób (bez objawów ZJN). W surowicy pacjentów wykonano oznaczenia stężenia przeciwciał klasy IgG przeciwko alergenom pokarmowym zawartym w 8 mieszankach alergenów. Stężenie przeciwciał zbadano metodą immunoenzymatyczną. Obliczenia wykonano w programie Stata v.10

Wyniki: Pozytywne wyniki testów uzyskano u ponad $90 \%$ osób z ZJN. Dla trzech badanych mieszanek alergenów wszystkie wyniki były pozytywne, dla pozostałych dodatnie miano IgG występowało u co najmniej $95 \%$ badanych pacjentów. W grupie kontrolnej wyniki były podobne. 
2. Elevated level of IgG in serum is probably the organism's response to the products consumed rather than an expression of hyperresponsiveness to allergens contained therein.

\section{Introduction}

Irritable bowel syndrome (IBS) is a functional bowel disorder, which manifests discomfort or abdominal pain associated with defecation or a change in bowel movement, and the act of defection goes wrong [1]. Irritable bowel syndrome occurs in approximately $10-12 \%$ of the population of developed countries [2-4]. Irritable bowel syndrome is a serious strain for patients. It is believed that this disease reduces the quality of life in a way similar to the effect seen in other chronic diseases, or greater than for example in gastroesophageal reflux disease, asthma or migraine $[5,6]$. In recent years the hypothesis that IBS symptoms result from allergies or food intolerance which have not been identified has been gaining more and more supporters. This view is supported by published findings showing that from $20 \%$ to $67 \%$ of patients diagnosed with IBS reported the presence of symptoms after eating food [7, 8]. Irritable bowel syndrome patients, suspecting the relationship of symptoms with consumed food, often eliminate some foodstuffs from the diet. The preparation of meals, eating outside the home and thus functioning in the family and society are hindered, negatively affecting the physical and emotional status of patients. At the same time, some patients refrain from eating products which have no connection with their health. This can lead however to undernutrition with respect to some nutrients. Irritable bowel syndrome patients do not gain the expected result, but impoverish their diet. Finding out what products in a defined population are responsible for the emergence of the disease, and by which mechanisms, could improve the health of many patients with IBS, by applying a proper diet. In recent years, attempts have been made to find a connection between the disorders identified in patients with IBS and food allergy, particularly lgG-dependent. The results obtained do not give a definite answer.

\section{Aim}

The main objective of this study was to evaluate the usefulness of tests for immunoglobulin $G(\mathrm{IgG})$ in patients with IBS against food allergens and the possible use of the obtained results for the introduction of an elimination diet.

\section{Wnioski:}

1. Oznaczanie przeciwciał klasy G nie znajduje zastosowania w diagnozowaniu alergii pokarmowych oraz modyfikowaniu diety pacjentów z ZJN.

2. Zwiększone stężenie IgG $w$ surowicy jest prawdopodobnie odpowiedzią organizmu na spożywane produkty, a nie wyrazem nadreaktywności na alergeny w nich zawarte.

\section{Material and methods}

The study was performed in the years 2007-2009 with the approval of the Bioethics Commission at the National Food and Nutrition Institute in Warsaw. The work was performed under the research project No. N404 052 31/2712 of the Ministry of Science and Higher Education: "Food allergy and coeliac disease in patients with irritable bowel syndrome (IBS). Study of the possibility of using probiotics and conjugated fatty acids (CLA) in the treatment of IBS and coeliac disease and food allergies associated with it". All persons participating in the study gave their written consent. The study included 100 patients with IBS treated at the gastrological clinic of Brodnowski Regional Hospital in Warsaw. The control group consisted of 50 healthy individuals (without symptoms of irritable bowel syndrome). The study excluded individuals chronically taking steroids, antihistamines or non-steroidal anti-inflammatory drugs, with a history of immunotherapy, after resection of the stomach, and with chronic systemic diseases and allergies. The average age of patients with IBS was 47 years, and in the healthy control group 43 years. The women predominated in the study; there were 76 women in the IBS group and 41 in the control group. In the serum IgG antibodies against food allergens contained in eight mixes were tested:

- Children Food Mix - egg white, cow's milk, cod, wheat, peanuts, soybeans,

- Vegetable mix - green beans, tomato, carrot, potato, celery,

- Cabbage mix - cabbage, Brussels sprouts, sprouts, broccoli, cauliflower,

- Spice mix - mustard, paprika, black pepper, nutmeg,

- Food Mix - sesame seeds, yeast, chocolate, cocoa, malt,

- Meat mix - pork, beef, chicken, turkey,

- Cake ingredients - rye, wheat, hazelnuts, almonds, egg, walnuts,

- Fruit mix - apple, orange, strawberry, kiwi, lemon, grapefruit.

The results, as recommended by the company producing the tests, were interpreted as follows: negative: $<1.0 \mathrm{mg} / \mathrm{ml}$, and positive results in four classes: I: $1-2.99 \mathrm{mg} / \mathrm{ml}$, II: 3.0-9.99 $\mu \mathrm{g} / \mathrm{ml}$, III: $10.0-29.9 \mathrm{mg} / \mathrm{ml}$, IV > $30 \mu \mathrm{g} / \mathrm{ml}$. On the basis of test results obtained 
for mixes of food allergens it was decided to abandon the study of specific IgG.

The concentration of antibodies was examined by enzyme immunoassay (EIA) test using the HY TEC system. Calculations were performed in Stata v.10 (Stata Statistical Software: Release 10, College Station, TX, Stata Corporation LP 2007). Results with $p<0.05$ were acknowledged as statistically significant values.

\section{Results}

Positive results denoting the concentrations were found in more than $90 \%$ of people with IBS (Table I). For the three tested mixtures of allergens - Spice Mix, Food Mix and Meat Mix - all the results were positive, and the remaining positive IgG titre occurred in at least $95 \%$ of the patients. In the control group results were similar. In the serum of all patients without IBS symptoms an elevated concentration of IgG against the allergens contained in the three mixes was found, but they were mixtures other than those in the study group: Vegetable Mix, Fruit Mix, Cake ingredients. Seventy-six percent of subjects in the control group reacted to allergens contained in the mixture Cake ingredients, and from $88 \%$ to $98 \%$ of people from this group reacted to other allergens. In the control group there were significantly more positive results of the concentration of IgG antibodies to the Children Food Mix, Vegetable Mix, Fruit Mix, and Cake ingredients. However, patients with IBS reported significantly more positive results for Spice Mix, Food Mix and Meat Mix.

IgG levels for most allergen sources were high in almost all patients, especially in the control group. $74-100 \%$ of individuals in this group corresponded to the IgG-mediated reaction of III (10.0-29.9 $\mathrm{mg} / \mathrm{ml})$ and IV (> $30 \mu \mathrm{g} / \mathrm{ml}$ ) class to allergens from 6 to 8 investigated mixes. In the serum of IBS patients the highest levels of IgG antibodies were determined from $2 \%$ to $40 \%$ of persons depending on the mix of allergens. Other results were also positive, but were in class I and II. Only individuals did not respond to the IgG-mediated reaction to the tested allergens. In the control group, significantly more positive results for IgG antibody concentrations in the mixtures Children Food Mix (egg, cow's milk, cod, wheat, peanuts, soy), Vegetable Mix (green beans, tomato, carrot, potato, celery), Fruit Mix (apple, orange, strawberries, kiwi, lemon, grapefruit) and Cake ingredients (rye, wheat, hazelnuts, almonds, egg, walnuts) were found.

\section{Discussion}

As shown, the results of studies evaluating the usefulness of IgG in the diagnosis of delayed food allergy in patients with IBS are ambiguous. The results presented in their own work does not permit the recommendation of this procedure in detecting food allergies, and the more entry on the basis of test results obtained diet. Individuals in the control group reported virtually no symptoms, although concentrations of IgG in their sera were higher than in IBS patients. At the current level of knowledge, determining the concentration of IgG in the serum of patients with IBS is not justified. Results obtained in this study confirm reports by other authors, both those already published in the 1990s [9-11], and the latest [12, 13], although some researchers have recognized the benefits of testing serum IgG concentration in IBS patients [14-16]. Kruszewski et al. [10, 11] also found that elevated levels of IgG are equally common in healthy people and people who are allergic. This led the authors to conclude that concentrations of IgG have no significance in the induction of an allergic reaction, and the high IgG concentration in the serum depends on the consumption of products. The authors claimed that in this situation, the diagnostic role of IgG is irrelevant. Similar conclusions were reached by the team led by Maciorkowska et al. [9]. Also Kamer et al. [17], in a study in children with a predisposition to allergies, found increased levels of specific IgG antibodies in children without clinical symptoms of allergy. The authors concluded that the role of IgG in the pathogenesis of allergic reactions is ambiguous. The ambiguous role of IgG in the pathogenesis of food allergy is confirmed by the findings of U.S. and Norwegian studies $[12,18]$. It has been shown that patients reacting to cow's milk allergy by lgE-mediated reactions also produce higher amounts of IgG1 and lgG4. Acquisition of tolerance to milk leads to lower patients' blood serum levels of IgE, IgG, IgG1 and IgG4 antibodies. The increased concentration of IgG in serum, as explained by some authors, may also result from successfully used oral immunotherapy. Teuber and Beyer [19], like other authors, have pointed out that the increase in the concentration of IgG in the blood of patients with IBS is probably related to products which are frequently eaten, but not those that are responsible for symptoms. Symptoms may be associated with other immunological processes, dysregulation of the immune system, the influence of nutrients on gastrointestinal microflora, independent of the concentration of IgG and use of oral immunotherapy. Simultaneously published studies support the theory of development of IBS symptoms by an IgG-dependent mechanism. Many of these studies were inspired by the results of Atkinson et al. and Dixon [14, 20] who found that elevated levels of IgG in the serum may be a marker of immune response being a manifestation of delayed-type food 
Table I. Results of tests identifying the concentration of IgG antibodies against food allergens

Tabela I. Wyniki testów oznaczających stężenie przeciwciał IgG przeciwko alergenom pokarmowym

\begin{tabular}{|c|c|c|c|c|c|c|}
\hline \multirow[t]{3}{*}{ Mixture of allergens } & \multirow[t]{3}{*}{$\lg G^{*}$ results } & \multicolumn{4}{|c|}{ Group } & \multirow[t]{3}{*}{ Value of $p^{\star \star}$} \\
\hline & & \multicolumn{2}{|c|}{ IBS, $N=100$} & \multicolumn{2}{|c|}{ Control, $N=50$} & \\
\hline & & $n$ & $\%$ & $n$ & $\%$ & \\
\hline \multirow{6}{*}{$\begin{array}{l}\text { Children Food Mix - egg white, } \\
\text { cow's milk, cod, wheat, peanuts, soybeans }\end{array}$} & Negative & 5 & 5 & 1 & 2 & \\
\hline & 1 & 16 & 16 & 9 & 18 & \\
\hline & $\|$ & 39 & 39 & 2 & 4 & \\
\hline & III & 39 & 39 & 33 & 66 & \\
\hline & IV & 1 & 1 & 5 & 10 & \\
\hline & I-IV & 95 & 95 & 48 & 96 & $<0.001$ \\
\hline \multirow{6}{*}{$\begin{array}{l}\text { Vegetable Mix - green beans, tomato, carrot, } \\
\text { potato, celery }\end{array}$} & Negative & 4 & 4 & 0 & 0 & \\
\hline & 1 & 10 & 10 & 1 & 2 & \\
\hline & II & 82 & 82 & 3 & 6 & \\
\hline & III & 4 & 4 & 37 & 74 & \\
\hline & IV & 0 & 0 & 9 & 18 & \\
\hline & I-IV & 96 & 96 & 50 & 100 & $<0.001$ \\
\hline \multirow{6}{*}{$\begin{array}{l}\text { Cabbage Mix - cabbage, Brussels sprouts, } \\
\text { sprouts, broccoli, cauliflower }\end{array}$} & Negative & 4 & 4 & 6 & 12 & \\
\hline & 1 & 23 & 23 & 7 & 14 & \\
\hline & II & 71 & 71 & 33 & 66 & \\
\hline & III & 2 & 2 & 4 & 8 & \\
\hline & IV & 0 & 0 & 0 & 0 & \\
\hline & I-IV & 96 & 96 & 44.0 & 88 & 0.098 \\
\hline \multirow{6}{*}{$\begin{array}{l}\text { Fruit Mix - apple, orange, strawberries, kiwi, } \\
\text { lemon, grapefruit }\end{array}$} & Negative & 1 & 1 & 0 & 0 & \\
\hline & 1 & 11 & 11 & 0 & 0 & \\
\hline & II & 39 & 39 & 14 & 28 & \\
\hline & III & 46 & 46 & 36 & 72 & \\
\hline & IV & 3 & 3 & 0 & 0 & \\
\hline & I-IV & 99 & 99 & 50 & 100 & 0.009 \\
\hline \multirow{6}{*}{$\begin{array}{l}\text { Spice Mix - mustard, paprika, black pepper, } \\
\text { nutmeg }\end{array}$} & Negative & 0 & 0 & 3 & 6 & \\
\hline & I & 18 & 18 & 18 & 36 & \\
\hline & II & 73 & 73 & 29 & 58 & \\
\hline & III & 9 & 9 & 0 & 0 & \\
\hline & IV & 0 & 0 & 0 & 0 & \\
\hline & I-IV & 100 & 100 & 47 & 94 & 0.029 \\
\hline \multirow{6}{*}{$\begin{array}{l}\text { Cake ingredients - rye, wheat, hazelnuts, } \\
\text { almonds, egg, walnuts }\end{array}$} & Negative & 3 & 3 & 0 & 0 & \\
\hline & 1 & 23 & 23 & 0 & 0 & \\
\hline & II & 60 & 60 & 0 & 0 & \\
\hline & III & 14 & 14 & 11 & 22 & \\
\hline & IV & 0 & 0 & 39 & 78 & \\
\hline & I-V & 97 & 97 & 50 & 100 & $<0.001$ \\
\hline \multirow{6}{*}{$\begin{array}{l}\text { Food Mix - sesame seeds, yeast, chocolate, } \\
\text { cocoa, malt }\end{array}$} & Negative & 0 & 0 & 1 & 2 & \\
\hline & 1 & 11 & 11 & 3 & 6 & \\
\hline & II & 63 & 63 & 11 & 22 & \\
\hline & III & 23 & 23 & 34 & 68 & \\
\hline & IV & 3 & 3 & 1 & 2 & \\
\hline & I-IV & 100 & 100 & 49 & 98 & $<0.001$ \\
\hline
\end{tabular}


Table I. Cont.

Tabela I. Cd.

\begin{tabular}{|c|c|c|c|c|c|c|}
\hline \multirow[t]{3}{*}{ Mixture of allergens } & \multirow[t]{3}{*}{$\lg G^{*}$ results } & \multicolumn{4}{|c|}{ Group } & \multirow[t]{3}{*}{ Value of $p^{\star \star}$} \\
\hline & & \multicolumn{2}{|c|}{ IBS, $N=100$} & \multicolumn{2}{|c|}{ Control, $N=50$} & \\
\hline & & $n$ & $\%$ & $n$ & $\%$ & \\
\hline \multirow[t]{6}{*}{ Meat Mix - pork, beef, chicken, turkey } & Negative & 0 & 0 & 0 & 0 & \\
\hline & 1 & 2 & 2 & 12 & 24 & \\
\hline & ॥ & 81 & 81 & 38 & 76 & \\
\hline & III & 17 & 17 & 0 & 0 & \\
\hline & IV & 0 & 0 & 0 & 0 & \\
\hline & I-IV & 100 & 100 & 38 & 76 & 0.001 \\
\hline
\end{tabular}

${ }^{*}$ Negative result < $1.0 \mu \mathrm{g} / \mathrm{ml}$, I: 1-2.99 $\mu \mathrm{g} / \mathrm{ml}$, II: 3.0-9.99 $\mu \mathrm{g} / \mathrm{ml}$, III: 10.0-29.9 $\mu \mathrm{g} / \mathrm{ml}, \mathrm{N}>30 \mu \mathrm{g} / \mathrm{ml}$, **Fisher test

hypersensitivity. According to this theory, a diet prepared on the basis of IgG can be an effective way to relieve symptoms in patients with IBS [14] and patients with symptoms of delayed allergic reaction [20]. It should be noted, however, that the conclusions of the authors relied solely on the results of studies on the concentration of IgG in groups without control. Hunter [13] on the basis of Atkinson's et al. published work [14] states that the determination of IgG in the serum of patients with IBS is not useful because high concentrations of immunoglobulins of this class were found in the sera of all patients in a number of tested allergens. It seems unlikely that the whole group responded to the IgG-dependent allergy. He also drew attention to the fact that a positive titre of test immunoglobulin was observed in all patients. Similar conclusions were reached by Zar et al. [15, 16], who obtained positive results in patients with IBS after elimination from the diet of products which achieved higher concentrations of IgG. The study found that people with IBS produce more IgG in response to certain allergens, compared to the control group. Zar et al. [15] showed that patients with significantly stronger IBS respond to an IgG-mediated reaction to certain allergens, compared to patients without symptoms of this syndrome. Similarly, Oh et al. [21] believe that the determination of IgG may be useful in diagnosing food allergies and predict the development of atopic dermatitis. These authors obtained a positive titre for lgE/lgG4 for about $30 \%$ of sources of food allergens. Similar conclusions were reached by Drisko et al. [22], who obtained positive effects excluding from the diet sources of allergens to which patients with IBS responded with an IgG-mediated reaction. However, in this case the serum IgG concentration in the control group was not examined and positive results were obtained in $40-80 \%$ of subjects on such widely consumed products as yeast, pork, onion, cheddar cheese, carrots, egg, wheat, nuts, and soybeans. In this work, IgE levels were tested for sources of food allergens and the results were also used to develop the elimination diet. It was not specified which allergens were responsible for elevated IgE titre. The applied diet had positive effects, but it seems that these results should be treated with some degree of doubt, especially since the study did not include a control group, and the number of positive tests indicates that some people would eliminate up to 10 commonly consumed items. During the intervention probiotic was used, which probably had an impact on improving the welfare of patients. Also, Yang and Li [23] stated that in the blood serum of patients with IBS, concentrations of specific IgG food allergens are higher than in those without the characteristics of this syndrome. In addition, they demonstrated that IgG-mediated reactions more often occur among patients with diarrhoea (63.6\%) than those with constipation (43.8\%) form of the disease, and the use of an elimination diet based on the results of IgG results in improved health of the subjects. Teuber and Beyer [19] express concern that the views on the role of IgG in food allergies promoted in recent years could be commercially motivated. Companies offer the possibility of determining the total concentration of IgG, its subclasses, or a combination. Some companies even offer rotation diets for patients on the basis of test results obtained, though so far the effectiveness of such a procedure has not been properly verified.

\section{Conclusions}

1. Determination of antibody class $G$ is not applicable to the diagnosis of food allergies and dietary modification in patients with IBS.

2. Elevated level of IgG in serum is probably the organism's response to products included in the diet rather than expression of hyperresponsiveness to allergens contained therein. 


\section{References}

1. Longstreth GF, Thompson WG, Chey WD, et al. Functional bowel disorders. Gastroenterology 2006; 130: 1480-91.

2. Drossman DA, Camilleri M, Mayer EA, et al. AGA technical review on irritable bowel syndrome. Gastroenterology 2002; 123: 2108-31.

3. Hungin AP, Chang L, Dennis EH, et al. Irritable bowel syndrome in the United States: symptom patterns and impact. Aliment Pharmacol Ther 2005; 21: 1365-75.

4. Quigley EM, Bytzer P, Jones R, et al. Irritable bowel syndrome: the burden and unmet needs in Europe. Dig Liver Dis 2006; 38: 717-23.

5. Dean BB, Aguilar D, Barghout $\mathrm{V}$, et al. Impairment in work productivity and health-related quality of life in patients with IBS. Am J Manag Care 2005; 11: 17-26.

6. Brun-Strang C, Dapoigny M, Lafuma A, et al. Irritable bowel syndrome in France: quality of life, medical management, and costs: the Encoli study. Eur J Gastroenterol Hepatol 2007; 19 : 1097-103.

7. Teufel M, Biedermann T, Rapps N, et al. Psychological burden of food allergy. World J Gastroenterol 2007; 13: 3456-65.

8. Shepherd SJ, Parker FC, Muir JG, et al. Dietary triggers of abdominal symptoms in patients with irritable bowel syndrome: randomized placebo-controlled evidence. Clin Gastroenterol Hepatol 2008; 6: 765-71.

9. Maciorkowska E, Kaczmarski M, Werpachowska I, et al. Influence of cellular and humoral immunity in the formation and nature of allergic symptoms in children and adolescents. Przegl Pediatr 1997; 1 (Suppl): 26-8.

10. Kruszewski J, Rączka A, Kłos M, et al. High serum levels of allergen specific lgG-4 (aslgG-4) for common food allergens in healthy blood donors. Arch Immunol Ther Exp 1994; 42: 259-61.

11. Kruszewski J, Rączka A, Kłos M, et al. Allergen specific IgG 4 (aslgG 4) for common food allergens in patients with food allergy, food intolerance and for suspected food allergy and in healthy people and it's dependence on diet. Int Rev Allergol Clin Immunol 1995; 1: 24-32.

12. Shek LPC, Bardina L, Castro R, et al. Humoral and cellular responses to cow milk proteins in patients with milk-induced IgE-mediated and non-IgE-mediated disorders. Allergy 2005; 60: 912-9.

13. Hunter JO. Food elimination in IBS: the case for IgG testing remains doubtful. Gut 2005; 54: 1203.

14. Atkinson W, Sheldon TA, Shaath N, et al. Food elimination based on IgG antibodies in irritable bowel syndrome: a randomised controlled trial. Gut 2000; 53: 1459-64.

15. Zar S, Benson MJ, Kumar D. Food-specific serum IgG4 and IgE titers to common food antigens in irritable bowel syndrome. Am J Gastroenterol 2005; 100: 1550-7.

16. Zar S, Mincher L, Benson MJ, et al. Food-specific IgG4 antibody-guided exclusion diet improves symptoms and rectal compliance in irritable bowel syndrome. Scand J Gastroenterol 2005; 40: 800-7.

17. Kamer B, Kaczmarek J, Lukamowicz J. The occurrence of allergen-specific IgE and IgG4 in infants and young children with food allergy. Alerg Ast Immunol 1998; 3: 171-3.

18. Sletten GB, Halvorsen R, Egaas E, et al. TS. Casein-specific immunoglobulins in cow's mild allergic patient subgroups reveal a shift to IgA dominance in tolerant patients. Pediatr Allergy Immunol 2007; 18: 71-80.

19. Teuber SS, Beyer K. IgG to foods: a test not ready for prime time. Curr Opin Allergy Clin Immunol 2007; 7: 257-8.

20. Dixon HS. Treatment of delayed food allergy based on specific immunoglobulin G RAST testing. Otolaryngol Head Neck Surg 2000; 123: 48-54.

21. Oh J, Ahn H, Lee $\mathrm{S}$, et al. The clinical significance of food specific IgE/lgG4 in food specific atopic dermatitis. J Allergy Epidemiol 2005; 115 (Suppl): 102.

22. Drisko J, Bischoff B, Hall M, et al. Treating irritable bowel syndrome with a food elimination diet followed by food challenge and probiotics. J Am Coll Nutr 2006; 6: 514-22.

23. Yang CM, Li YQ. The therapeutic effects of eliminating allergic foods according to food-specific IgG antibodies in irritable bowel syndrome. Zhonghua Nei Ke Zhi 2007; 46: 641-43. 